\title{
Temperature and light in seed germination of Myrceugenia myrtoides $\mathbf{O}$. Berg ${ }^{(1)}$
}

\author{
LUCIANA PINTO PAIM(2)*, EDUARDA DEMARI AVRELLA ${ }^{(2)}$, AQUELIS ARMILIATO EMER(2), \\ MONIQUE CAUMO(2), LUCIANO DA SILVA ALVES ${ }^{(2)}$, CLAUDIMAR SIDNEI FIOR ${ }^{(2)}$
}

\begin{abstract}
Myrceugenia myrtoides (Myrtaceae) is a species of tree size, occurring restricted to the state of Rio Grande do Sul state in Brazil, and Uruguay, presenting ornamental potential. The interest in native species for diverse uses is increasing, but their insertion is limited due to the lack of information on its propagation and cultivation. Thus, the objective of this study was to evaluate the effects of temperature and light on the germination of M. myrtoides seeds, in order to generate information that could aid in the propagation of the species and the exploration of its potential. The effects of constant temperatures of 20,25 and $30{ }^{\circ} \mathrm{C}$ under a 16-hour photoperiod were evaluated. To evaluate the effect of light, the germination was tested in continuous darkness and under photoperiod of 16 hours, at a temperature of $25^{\circ} \mathrm{C}$ and light intensity of 27 and $33.75 \mu \mathrm{mol} \mathrm{m}^{-2} \mathrm{~s}^{-1}$ under white light quality and diffuse green light. The results showed a lower average germination time at temperatures of 25 and $30^{\circ} \mathrm{C}$ and a higher accumulation of dry mass under $30^{\circ} \mathrm{C}$. There was superiority in the variables of seedling formation, shoot and root length and seedling formation under the number of seeds germinated at $25^{\circ} \mathrm{C}$. However, the different light conditions tested did not affect the percentage of germination. It is concluded that the temperature of $25{ }^{\circ} \mathrm{C}$ was the most adequate for seed germination and development of $M$. myrtoides seedlings and their seeds are classified as neutral photoblasts.
\end{abstract}

Keywords: guamirim, native species, ornamental, propagation.

\section{RESUMO}

Temperatura e luz na germinação de sementes de Myrceugenia myrtoides O. Berg

Myrcengenia myrtoides (Myrtaceae) é uma espécie de porte arbóreo, com ocorrência restrita ao estado do Rio Grande do Sul no Brasil, e Uruguai, apresentando potencial ornamental. O interesse em espécies nativas para usos diversos é crescente, mas sua inserção é limitada devido à falta de informações sobre sua propagação e cultivo. Assim, o objetivo deste estudo foi avaliar os efeitos de temperatura e luz na germinação das sementes de M. myrtoides, a fim de gerar informações que possam auxiliar na propagação da espécie e exploração do seu potencial. Avaliaram-se os efeitos das temperaturas constantes de 20,25 e $30{ }^{\circ} \mathrm{C}$ sob fotoperíodo de 16 horas. Para avaliar o efeito da luz, a germinação foi testada em ausência total de luz e sob fotoperíodo de 16 horas, na temperatura de $25^{\circ} \mathrm{C}$ e intensidade luminosa de 27 e $33,75 \mu \mathrm{mol} \mathrm{m} \mathrm{m}^{-2} \mathrm{~s}^{-1}$, sob qualidade de luz branca e luz verde difusa. Os resultados demonstraram menor tempo médio de germinação nas temperaturas de 25 e $30^{\circ} \mathrm{C}$ e ainda, maior acúmulo de massa seca sob $30^{\circ} \mathrm{C}$. Houve superioridade nas variáveis de formação de plântula, comprimento de parte aérea e raiz e formação de plântulas sob número de sementes germinadas para a temperatura de $25^{\circ} \mathrm{C}$. Já as diferentes condições de luz testadas não afetaram a porcentagem de germinação. Conclui-se que a temperatura de $25{ }^{\circ} \mathrm{C}$ foi a mais adequada para a germinação de sementes e desenvolvimento de plântulas de M. myrtoides e as suas sementes são classificadas como fotoblásticas neutras.

Palavras-chave: guamirim, espécie nativa, ornamental, propagação.

\section{INTRODUCTION}

The Myrtaceae family is one of the most important in several Brazilian vegetable formations, especially the forests (GRESSLER et al., 2006), and is represented by 23 genera and 1.028 species (REFLORA, 2018). In Rio Grande do Sul state, Myrtaceae is the family with the largest number of specimens in the tree flora (SOBRAL, 2003). Among them, Myrceugenia myrtoides O. Berg, a species with restricted occurrence in Rio Grande do Sul State in Brazil and Uruguay stands out in the forest and non-forest domains of the Mata Atlântica and the Pampa biomes, in environments ranging from clean grasslands to riparian forests, especially in the Semidecidual Seasonal Forest (REFLORA, 2018).

The species is commonly known as 'guamirim'. It can reach up to 4 meters in height and its leaves are ovateelliptic shaped with sharp apex and markedly discolor

DOI: http://dx.doi.org/10.14295/oh.v24i3.1213

(1) Received in 18/05/2018 and accepted in 07/07/2018

${ }^{(2)}$ Universidade Federal do Rio Grande do Sul, Departamento de Horticultura e Silvicultura, Porto Alegre-RS, Brazil. * Corresponding author: lucianappaim@bol.com.br

Licensed by CC BY 4.0 
(Figure 1) (LANDRUM, 1981; SOBRAL, 2003). From the economic point of view, these attributes give the species a high potential for use as ornamental, mainly in the afforestation of squares and parks. In addition, it produces important fruits for feeding the birdlife, promoting the colonization of degraded areas.

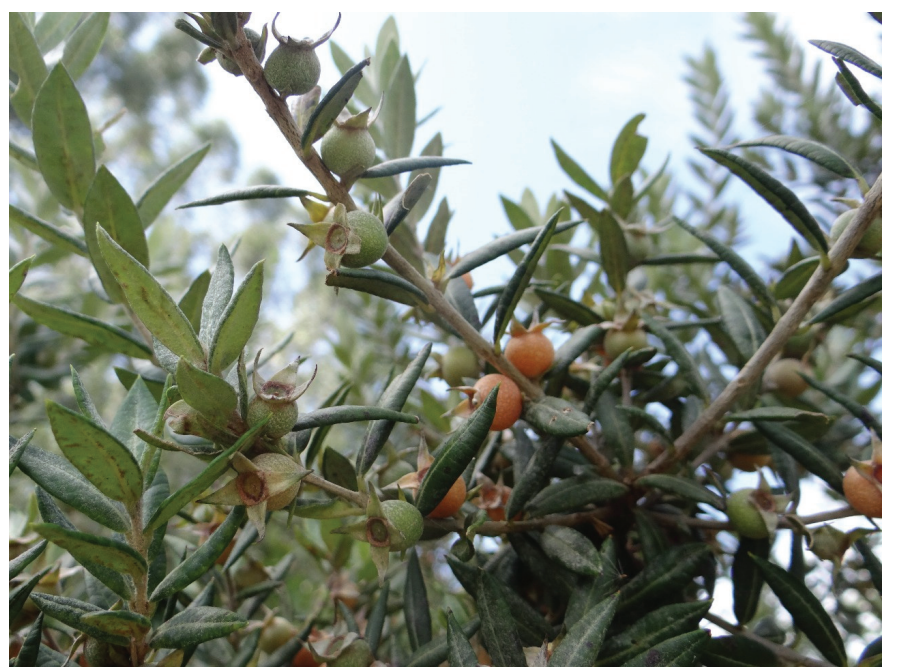

Figure 1. Adult plant of Myrceugenia myrtoides, Pantano Grande, RS, 2016.

According to Carrion and Brack (2012), there are several native species that present high ornamental potential, but their supply remains scarce due to lack of information, specially related to propagation and cultivation. Therefore, many exotic species consecrated and accepted by the population remain inadequately used in landscaping (LEAL and BIONDI, 2006).

The use of native species helps to maintain the associated regional flora and fauna, and are more suited to local climatic conditions (ALOUFA and MEDEIROS, 2016). Furthermore, the interest in propagation of native species is increasing, especially for the fruit and forest species with ornamental potential and for recovery of degraded areas (CORADIN et al., 2011), as M. myrtoides. Therefore, since it can occur both in areas of grasslands and in forest formations, this species presents characteristics of ecological plasticity (REFLORA, 2018) and multiple uses potential.

The floristic composition of the Brazilian forests is extremely heterogeneous, presenting species with different physiological behaviors (MAGISTRALI et al., 2013). Therefore, it is essential to know the ideal conditions for the germination process to occur normally, mainly because the species can present varied responses to different factors (CARVALHO and NAKAGAWA, 2012). Thus, for the purposes of propagation, it is necessary to use methodologies for the analysis of seeds, aiming to generate information that helps in the characterization of its physiological attributes and the improvement in the seed germination pattern.

Germination is regulated by the interaction of the physiological stage of the seed and environmental conditions, in which each plant species needs a set of specific requirements for this process, such as availability of water, temperature, light and oxygen, fundamental in the sexual propagation (MONDO et al., 2010). Among these, the temperature has a relevant ability to interfere in all biochemical reactions and physiological processes, intervening in the speed and percentage of germination (CARVALHO and NAKAGAWA, 2012; MARCOS FILHO, 2015). Another very important factor is light, whose response will depend on the luminous flux, quality and amount of light used on the process (REBOUÇAS and SANTOS, 2007).

The knowledge of the conditions that provide fast and uniform seed germination is extremely useful in propagating and exploiting its potential (ALVES et al., 2015), as Myrcengenia myrtoides. However, little is known about the factors that influence its germination. The objective of this work was to study the effects of temperature and light on germination of Myrceugenia myrtoides seeds.

\section{MATERIAL AND METHODS}

Ripe fruits with orange colour were collected from adult plants of $M$. myrtoides in situ, which were isolated and in full sun, located at latitude of $30^{\circ} 17^{\prime} 25.47^{\prime \prime} \mathrm{S}$ and longitude $52^{\circ} 27^{\prime} 56.50^{\prime \prime} \mathrm{W}$ (Figure 1). After the collection, the seeds went through processing, manual removed from fruits and washed in running water to eliminate the pulp and mucilage. After this procedure, the seeds were placed on a laboratory bench on absorbent paper to remove excess water.

The seeds were submitted to disinfestation process from immersion in $50 \%$ ethanol for one minute, followed by $1.5 \%$ sodium hypochlorite plus five drops of Tween 20 for 15 minutes. For the removal of residues from the disinfestation agents, the seeds were washed three times in autoclaved deionized water, each rinsing one minute. After this process, the seeds were submitted to constant temperatures of 20,25 and $30^{\circ} \mathrm{C}$ and established in gerbox boxes containing as substrate a sheet of germibox paper 
moistened with deionized water in the proportion of 2.5 times the mass of the dry paper (BRASIL, 2009). The boxes were maintained in incubator chambers BOD (Biochemical Oxygen Demand) with photoperiod of $16 \mathrm{~h}$.

The photoblastic test was performed in BOD type chamber with photoperiod of $16 \mathrm{~h}$. in constant temperature of $25{ }^{\circ} \mathrm{C}$ and luminous intensity of 27 to $33.75 \mu \mathrm{mol}$ $\mathrm{m}^{-2} \mathrm{~s}^{-1}$. The conditions of lighting quality were with light (2.000 lux), diffuse green light (1.300 lux) and continuous darkness. The white light was provided by fluorescent lamps $(30 \mathrm{~W})$; the diffuse green light was obtained by the wrapping of the gerbox plastic boxes with sheets of cellophane paper in green color; and for treatment with no light, the boxes were wrapped with aluminum foil and arranged in carton. A luminometer of Panlux - Gossen Eletronic 2 brand was used to determine the luminous intensity.

The seed viability evaluations consisted of daily counting of the number of germinated seeds and normal seedlings formed, using as a germination parameter the radicle protrusion with $2 \mathrm{~mm}$ in length and, as a parameter for the formation of seedlings, those that presented normal aerial part and root system formed. In the photoblastic test, in the total absence of light, counting of germinated seeds and normal seedlings formed only at the end of the experiment.

After the evaluations, the following variables were calculated: percentage of germination $(\mathrm{G})$ and seedling formation (SF) - according to total normal seedlings; percentage of seedling formation on the number of germinated seeds (SP/NGS); germination rate index (GRI) according to the formula suggested by Maguire (1962); mean germination time (MGT) and mean time of seedling formation (TSF), according to the formula proposed by Silva and Nakagawa (1995). In addition, measurements of shoot and root length of the normal seedlings formed were performed with the aid of a graduated ruler $(\mathrm{mm})$; and determination of the dry mass of the plants, which were placed in bags of Kraft paper and submitted to oven drying at $65{ }^{\circ} \mathrm{C}$ until constant weight.

A completely randomized design with four replicates of 25 seeds was used, totaling 100 seeds per treatment. Data were submitted to analysis of variance (ANOVA), followed by comparison of means by the MSD test (minimum significant difference) at the level of 5\% of error probability, using CoStat software 6.4. For the variables of germination velocity and shoot length, transformations of $\mathrm{e}^{2}$, respectively, were performed. In addition, data on germination percentage, root length and dry mass of seedlings did not meet ANOVA assumptions even after data transformation, and therefore were submitted to non-parametric analysis by the Kruskal-Wallis test, with subsequent comparison the MSD test.

\section{RESULTS AND DISCUSSION}

Data analysis showed no influence of temperatures on germination percentage, germination speed index and mean time of seedling formation of $M$. myrtoides (Table 1). According to Reflora (2018), the distribution of the genus Myrceugenia by several Brazilian states causes their species to occupy the phytogeographic domains of the Caatinga, Cerrado, Mata Atlântica and Pampa. This fact, therefore, allows the plants of this genus to develop a wide plasticity and adaptation to different regions and environmental variations, as morphological, physiological or phenological, which justifies the fact that there was no influence of the temperatures tested on the germination of the seeds of the species under study.

Table 1. Mean of germination percentage data, mean germination time, germination rate index and mean time of seedling formation according to the different temperatures in the germination process of M. myrtoides seeds.

\begin{tabular}{|c|c|c|c|c|}
\hline Temperature & G (\%) & MGT (days) & GRI & TSF (days) \\
\hline $20^{\circ} \mathrm{C}$ & $100^{\mathrm{ns}}$ & $5.31 \mathrm{~b}$ & $7.83^{\mathrm{ns}}$ & $10.71^{\mathrm{ns}}$ \\
\hline $25^{\circ} \mathrm{C}$ & 100 & $2.95 \mathrm{a}$ & 11.29 & 8.05 \\
\hline $30^{\circ} \mathrm{C}$ & 99 & $2.86 \mathrm{a}$ & 11.80 & 9.96 \\
\hline $\mathrm{P}-$ Value & 0.3679 & 0.0103 & 0.0527 & 0.1053 \\
\hline $\mathrm{CV}(\%)$ & $*$ & 26.60 & 11.08 & 16.76 \\
\hline
\end{tabular}

${ }^{\text {ns }}$ not significant at $5 \%$ probability of error; * non-parametric analysis, Kruskal-Wallis test; $\mathrm{CV}=$ coefficient of variation; $\mathrm{G}(\%)=$ percentage of germination; MGT (days) = mean germination time; GRI = germination rate index; TSF (days) = mean time of seedling formation. In column, means followed by lower case letters do not differ from one another by the LSD test (5\%).

The mean germination percentage of $M$. myrtoides seeds was $99.7 \%$. According to Cosmo et al. (2017), the high percentages of germination appear to be common in species of the Myrtaceae family. For Campomanesia xanthocarpa (Mart.) O. Berg., approximately $90 \%$ of germination was obtained, and for Campomanesia pubescens (DC.) O.
Berg. and Acca selowiana (O.Berg) Burret. the values were higher than 90\% (GOGOSZ et al., 2010; DOUSSEAU et al., 2011; GOMES et al., 2016).

For the germination speed index there was also no significant difference between the temperatures, as was observed for seeds of Myrceugenia euosma (O. Berg) D. 
Legrand., Curitiba prismatica (D. Legrand) Salywon \& Landrum and Blepharocalyx salicifolius (H.B.K.) Berg. (REGO et al., 2009; REGO et al., 2011; COSMO et al., 2017).

The mean germination time is a parameter of great importance for determination of seed vigor, since it is based on the assumption that the most vigorous seeds germinate in a shorter time (PIÑA-RODRIGUES et al., 2004). The data of the average germination time of the study species were less than three days at temperatures of 25 and $30^{\circ} \mathrm{C}$, in other words, the germination process of $M$. myrtoides is considered fast when compared to the mean time of 12 days of M. euosma species obtained by Cosmo et al. (2017).

The rate of occupation of a species in a community may depend on the mean germination time (FERREIRA et al., 2010). Characteristics of accelerated and uniform germination of seeds with subsequent emergence of seedlings are important aspects for the formation of seedlings, therefore the species is less susceptible to adverse environmental conditions (MARTINS et al., 2009), increasing the possibilities of establishment of seedlings.

The definition of the optimum temperature is very important to express the maximum physiological potential in seed germination and seedling formation (BRANCALION et al., 2008), since it favors the processes of speed of water absorption and biochemical reactions (MARCOS FILHO, 2015). For M. myrtoides, the values of the percentage of seedling formation and the formation of seedlings on the number of germinated seeds showed satisfactory results for the temperature of $25^{\circ} \mathrm{C}$, both with 99\% germination (Table 2). The knowledge of the appropriate temperature during the formation of seedlings is essential for the propagation of native species, especially in this initial and critical phase of the plant life cycle, since, according to Gomes et al. (2015), is a stage of marked vulnerability to environmental change.

Table 2. Percentage of seedling formation, shoot length and root length, dry mass of seedlings and percentage of seedling formation on the number of germinated seeds, according to the different temperatures in the germination process of $M$. myrtoides seeds.

\begin{tabular}{|c|c|c|c|c|c|}
\hline Temperature & SF (\%) & SL $(\mathbf{m m})$ & RL $(\mathbf{m m})$ & DM $(\mathbf{g})$ & SF/NGS $(\%)$ \\
\hline $20^{\circ} \mathrm{C}$ & $94.00 \mathrm{ab}$ & $14.71 \mathrm{c}$ & $21.18 \mathrm{~b}$ & $0.015 \mathrm{~b}$ & $94.00 \mathrm{ab}$ \\
\hline $25^{\circ} \mathrm{C}$ & $99.00 \mathrm{a}$ & $26.56 \mathrm{a}$ & $37.21 \mathrm{a}$ & $0.013 \mathrm{~b}$ & $99.00 \mathrm{a}$ \\
\hline $30^{\circ} \mathrm{C}$ & $89.92 \mathrm{~b}$ & $21.45 \mathrm{~b}$ & $21.12 \mathrm{~b}$ & $0.020 \mathrm{a}$ & $89.00 \mathrm{~b}$ \\
\hline $\mathrm{P}-$ Value & $<0.01$ & $<0.01$ & 0.0249 & 0.0183 & 0.0148 \\
\hline $\mathrm{CV}(\%)$ & 3.62 & 8.23 & $*$ & $*$ & 3.65 \\
\hline
\end{tabular}

\footnotetext{
* non-parametric analysis, Kruskal-Wallis test; CV = coefficient of variation; SF (\%) = percentage of seedling formation; $\mathrm{SL}=$ shoot length; RL = root length; DM = dry mass of seedlings; \%(SF/NGS) = percentage of seedling formation on the number of germinated seeds. In the column, means followed by lower case letters do not differ from each other by the LSD test $(5 \%)$.
}

Another parameter that assists in the indication of seed vigor is the growth of the seedlings. The aerial and root length of the $M$. myrtoides seedlings were higher when kept at $25^{\circ} \mathrm{C}$, with a mean growth of 26.56 and $37.21 \mathrm{~mm}$, respectively (Table 2). A similar result was observed for Campomanesia adamantium (Camb.) O. Berg, which also showed superior root and shoot growth at $25^{\circ} \mathrm{C}(\mathrm{DRESCH}$ et al., 2012).

In contrast, the dry matter of $M$. myrtoides showed superiority when maintained at a temperature of $30^{\circ} \mathrm{C}$ (Table 2), behavior that may be related to a high temperature stress on germination. In response to stress, there is an increase in the activity of enzymes associated with hydrolysis of seed reserves, leading to the biosynthesis of new tissues (DEVI et al., 2007), which may have contributed to the increase of dry mass of seedlings.

In relation to the photoblastic test, no differences were observed in the germination of $M$. myrtoides seeds regardless of the light conditions that were exposed, thus being a neutral photoblastic species. Other species of the family Myrtaceae also present indifferent behavior to light, as observed for Eugenia brasiliensis, E. involucrata,
E. pyriformis, E. uniflora (LAMARCA et al., 2011) and Blepharocalyx salicifolius (REGO et al., 2009). However, other species of the same family showed positive photoblastism, such as Curitiba prismatica (REGO et al., 2011), Campomanesia guazumifolia, Acca sellowiana and Psidium cattleyanum (SANTOS et al., 2004).

The variations in the light responses constitute a mechanism of adaptation of the species to different niches of the environment (GUALTIERI and FANTI, 2015). Larger seeds, or seeds of later stages of succession, tend to be indifferent or have germination inhibited by light, whereas small seeds or pioneer species need light to germinate (KERBAUY, 2013). This occurs as a function of the relation between the red light lengths: extreme red, since in shade conditions the radiation is rich in extreme red and the environment is not favorable, for example, the germination of pioneer species need more quantity of red and blue radiation for the development of their seedlings (TAKAKI, 2015). The seeds of $M$. myrtoides present a mean of $3.82 \mathrm{~mm}$ in length, $3.30 \mathrm{~mm}$ in width and 2.42 $\mathrm{mm}$ in thickness (AVRELLA et al., 2017) and based on the results obtained in this study characterizing them as 
neutral photoblasts, indicates the plasticity of the species in occupying different environments, since its germination and development of the seedlings will be satisfactory both in the presence and absence of light.

Therefore, the focus on studies on the methods of seed germination analysis are the basis for the propagation of native species (COSMO et al., 2017). Thus, considering the set of information on the germination patterns of $M$. myrtoides, it can be inferred that it has very promising attributes to its propagation and establishment, confirming the hypothesis of being a promising species for use as ornamental and in the recovery of degraded areas, since the germination of the seeds occurs satisfactorily independent of luminosity and in a wide temperature variation, presenting capacity to form seedlings in a short period of time and with high percentage.

\section{CONCLUSIONS}

The temperature of $25{ }^{\circ} \mathrm{C}$ is the most suitable for seed germination and development of Myrceugenia myrtoides seedlings and their seeds are classified as neutral photoblasts.

\section{ACKNOWLEDGMENTS}

The authors thank Capes (Coordenação de Aperfeiçoamento de Pessoal de Nível Superior), CNPq (Conselho Nacional de Desenvolvimento Científico e Tecnológico) and FAPERGS (Fundação de Amparo à Pesquisa do Estado do Rio Grande do Sul) for the financial assistance and for the accomplishment of the research.

\section{AUTHORS CONTRIBUTIONS}

L.P.P.: Responsible for implementation, evaluation and writing of the article; E.D.A.: contributed to the implantation, evaluation and writing of the article; A.A.E.: contributed to the evaluation and writing of the article; M.C.: contributed to the writing of the article; L.S.A.: contributed to the writing of the article; C.S.F.: Professor adviser and responsible for the Biotechnology Laboratory, contributed to the development of the study and the writing of the article.

\section{REFERENCES}

ALOUFA, M.A.I.; MEDEIROS, J.A. Valorização e preservação da faveleira (C. quercifolius) para o desenvolvimento sustentável do semiárido brasileiro. OKARA: Geografia em debate, v.10, n.3, p.453-476, 2016.

ALVES, C.Z.; SILVA, J.B.; CÂNDIDO, A.C.S. Metodologia para a condução do teste de germinação em sementes de goiaba. Revista Ciência Agronômica, v.46, n.3, p.615-621, 2015. DOI: http://dx.doi.org/10.5935/18066690.20150045 .
AVRELLA, E.D.; EMER, A.A.; PAIM, L.P.; CAUMO, M.; ORLANDI, C.R.; FREITAS, E.M.; FIOR, C.S. Caracterização de frutos e sementes de Myrceugenia myrtoides O. Berg. Revista Congrega Urcamp, v.14, p.869-879, 2017.

BRANCALION, P.H.S.; NOVEMBRE, A.D.L.C.; RODRIGUES, R.R.; CHAMMA, H.M.C.P. Efeito da luz e de diferentes temperaturas na germinação de sementes de Heliovarpus pipayanensis L. Revista Árvore, v.32, n.2, p.225-232, 2008. DOI: http://dx.doi.org/10.1590/S010067622008000200005

BRASIL. Regras para análise de sementes. Brasília: Ministério da Agricultura, Pesca e Abastecimento, 2009. 399p.

CARRION, A.A.; BRACK, P. Eudicotiledôneas ornamentais dos campos do bioma Pampa no Rio Grande do Sul. Revista Brasileira de Horticultura Ornamental, v.18, n.1, p.23-37, 2012. DOI: http://dx.doi.org/10.14295/ rbho.v18i1.690

CARVALHO, N.M.; NAKAGAWA, J. Sementes: ciência, tecnologia e produção. 5.ed. Jaboticabal: FUNEP, 2012. 590 p.

CORADIN, L.; SIMINSKI, A.; REIS, A. Espécies Nativas da Flora Brasileira de Valor Econômico Atual ou Potencial: Plantas para o Futuro - Região Sul. 2.ed. Brasília: MMA, 2011. 934p.

COSMO, N.L.; GOGOSZ, A.M.; REGO, S.S.; NOGUEIRA, A.C.; UNIYOSHI, Y.S. Morfologia de fruto, semente e plântula e germinação de sementes de Myrceugenia euosma (O. Berg) D. Legrand (Myrtaceae). Floresta, v.47, n.4, p.479-488, 2017. DOI: http://dx.doi. org/10.5380/rf.v47i4.46933

DOUSSEAU, S.; ALVARENGA, A.A.; GUIMARÃES, R.M.; LARA, T.S.; CUSTÓDIO, T.N.; CHAVES, I.S. Ecofisiologia da germinação de sementes de Campomanesia pubescens. Ciência Rural, v.41, n.8, p.1362-1368, 2011. DOI: http://dx.doi.org/10.1590/S010384782011000800011

DEVI, R.; MUNJRAL, N.; GUPTA, A.K.; KAUR, N. Cadmium induced changes in carbohydrate status and enzymes of carbohydrate metabolism, glycolysis and pentose phosphate pathway in pea. Environmental and Experimental Botany, v.61, n.2, p.167-174, 2007.

DRESCH, D.M.; SCALON, S.P.Q.; MASETTO, T.E.; VIEIRA, M.C. Germinação de sementes de Campomanesia adamantium (Camb.) O. Berg em diferentes temperaturas e umidades do substrato. Scientia Forestalis, v.40, n.94, p.223-229, 2012. 
FERREIRA, M.G.R.; SANTOS, M.R.A.; SILVA, E.O.; GONÇALVES, E.P.; ALVES, E.U.; BRUNO, R.L.A. Emergência e crescimento inicial de plântulas de biribá (Rollinia mucosa (Jacq.) Baill) (Annonaceae) em diferentes substratos. Semina: Ciências Agrárias, v.31, n.2, p.373-380, 2010. DOI: http://dx.doi.org/10.5433/16790359.2010v31n2p373.

GOGOSZ, A.M.; COSMO, N.L.; BONA, C.; SOUZA, L.C. Morfoanatomia da plântula de Campomanesia xanthocarpa O. Berg. (Myrtaceae). Acta Botânica Brasílica, v.24, n.3, p.613-623, 2010. DOI: http://dx.doi.org/10.1590/S010233062010000300003 .

GOMES, J.P.; OLIVEIRA, L.M.; FERREIRA, P.I.; BATISTA, F. Substratos e temperaturas para teste de germinação em sementes de Myrtaceae. Ciência Florestal, v.26, n.4, p.285-293, 2016. DOI: http://dx.doi. org/10.5902/1980509821120.

GOMES, J.P.; OLIVEIRA, L.M.; FRANÇA, C.S.S.; DACOREGIO, H.M.; BORTOLUZZI, R.L.C. Caracterização morfológica de plântulas durante a germinação de sementes de Psidium cattleianum e Acca sellowiana (Myrtaceae). Ciência Florestal, v.25, n.4, p.1035-1042, 2015. DOI: http://dx.doi. org/10.5902/1980509820665.

GRESSLER, E.; PIZO, M.A.; MORELLATO, L.P.C. Polinização e dispersão de sementes em Myrtaceae do Brasil. Revista Brasileira de Botânica, v.29, n.4, p.509-530, 2006. DOI: http://dx.doi.org/10.1590/S010084042006000400002

GUALTIERI, S.C.J.; FANTI, S. Ecofisiologia da germinação de sementes. PINÃ-RODRIGUES, F.C.M.; FIGLIOLIA, M.B.; SILVA, A. Sementes Florestais: da ecologia a produção. Londrina: ABRATES, 2015. p.259275.

KERBAUY, G.B. Fisiologia Vegetal. 2ed. Rio de Janeiro: Guanabara Koogan, 2013. 431p.

LAMARCA, E.V.; SILVA, C.V.; BARBEDO, C.J. Limites térmicos para a germinação em função da origem de sementes de espécies de Eugenia (Myrtaceae) nativas do Brasil. Acta Botânica Brasílica, v.25, n.2, p.293-300, 2011. DOI: http://dx.doi.org/10.1590/S010233062011000200005 .

LANDRUM, L.R. A monograph of the genus Myrceugenia. Flora Neotropica, n.29, p.1-137, 1981.

LEAL, L.; BIONDI, D. Potencial ornamental de espécies nativas. Revista Científica Eletrônica de Engenharia Florestal, n.8, p.1-16, 2006.
MAGISTRALI, P.R.; JOSÉ, A.C.; FARIA, J.M.R.; GASPARIN, E. Physiological behavior of Genipa americana L. seeds regarding the capacity for desiccation and storage tolerance. Journal of Seed Science, v.35, n.4, p.495-500, 2013. DOI: http://dx.doi.org/10.1590/S231715372013000400011 .

MAGUIRE, J.D. Speed of germination: aid in selection and evaluation for seedling emergence and vigor. Crop Science, v.2, p.176-177, 1962. DOI: http://dx.doi.org/10.2135/crops ci1962.0011183X000200020033x

MARCOS FILHO, J. Fisiologia de sementes de plantas cultivadas. 2ed. Londrina: ABRATES, 2015. 660p.

MARTINS, C.C.; BOVI, M.L.A; SPIERING, S.H. Umedecimento do substrato na emergência e vigor de plântulas de pupunheira. Revista Brasileira de Fruticultura, v.31, n.1, p.224-230, 2009. DOI: http:// dx.doi.org/10.1590/S0100-29452009000100031.

MONDO, V.H.V.; CARVALHO, S.J.P.; DIAS, A.C.R.; MARCOS FILHO, J. Efeito da luz e temperatura na germinação de sementes de quatro espécies de plantas daninhas do gênero Digitaria. Revista Brasileira de Sementes, v.32, n.1, p.131-137, 2010. DOI: http://dx.doi. org/10.1590/S0101-31222010000100015.

PIÑA-RODRIGUES, F.C.M.; FIGLIOLIA, M.B.; PEIXOTO, M.C. Tecnologia de sementes: testes de qualidade. In: FERREIRA, A.G.; BORGHETTI, F. Germinação: do básico ao aplicado. Porto Alegre: Artmed, 2004. p.265-282.

REBOUÇAS, A.C.M.N.; SANTOS, D.L. Influência do fotoperíodo e qualidade de luz na germinação de sementes de Melocactus conoideus (Cactaceae). Revista Brasileira de Biociências, v.5, s.2, p.900-902, 2007.

REFLORA. Myrtaceae. Flora do Brasil 2020 em construção. Jardim Botânico do Rio de Janeiro. Available in: $\quad<$ http://reflora.jbrj.gov.br/reflora/floradobrasil/ FB10649> Access on: 20th April 2018.

REGO, S.S.; COSMO, N.L.; GOGOSZ, M.M.; KUNIYOSHI, Y.S.; NOGUEIRA, A.C. Caracterização morfológica e germinação de sementes de Curitiba prismatica (D. Legrand) Salywon \& Landrum. Revista Brasileira de Sementes, v.33, n.4, p.616-625, 2011. DOI: http://dx.doi.org/10.1590/S0101-31222011000400003.

REGO, S.S.; NOGUEIRA, A.C.; KUNIYOSHI, Y.S.; SANTOS, Á.F. Germinação de sementes de Blepharocalyx salicifolius (H.B.K.) Berg. em diferentes substratos e condições de temperaturas, luz e umidade. Revista Brasileira de Sementes, v.31, n.2, p.212-220, 2009. DOI: http://dx.doi.org/10.1590/S0101-31222009000200025 
SANTOS, C.M.R.; FERREIRA, A.G.; ÁQUILA, M.E.A. Características de frutos e germinação de sementes de seis espécies de Myrtaceae nativas do Rio Grande do Sul. Ciência Florestal, v.14, n.2, p.13-20, 2004. DOI: http:// dx.doi.org/10.5902/198050981802

SILVA, J.B.; NAKAGAWA, J. Estudos de fórmulas para cálculo de velocidade de germinação. Informativo Abrates, v.5, n.1, p.62-73, 1995.
SOBRAL, M. A família das Myrtaceae no Rio Grande do Sul. São Leopoldo: Unisinos, 2003. 215p.

TAKAKI, M. O fitocromo e a germinação de sementes de espécies florestais. PINÃ-RODRIGUES, F.C.M.; FIGLIOLIA, M.B.; SILVA, A. Sementes Florestais: da ecologia à produção. Londrina: ABRATES, 2015. p.276307. 